\title{
Observation on in vitro Development of Black at Hatch (Bh) Lethal Quail Embryos with Special Reference to Liver Morphogenesis
}

\author{
Tamao Ono and Noboru WaKasugI \\ Laboratory of Animal Genetics, School of Agriculture, Nagoya University, \\ Chikusa, Nagoya, 464, Japan.
}

\section{Introduction}

In newly hatched black at hatch $(B h)$ type quail, there is intermingling of yellow and black pigments in the dorsal down feathers ${ }^{1}$. This character is controlled by an autosomal dominant gene with homozygous lethality and the homozygous embryos die at 4 to 9 days of incubation showing whole body subcutaneous haemorrhage and degeneration of the liver tissue $^{1,2)}$. Moreover, local degeneration of liver tissue was observed at the posterior tip of the left lobe in some of the $B h$ heterozygous embryos at 10 to 15 days of incubation. This abnormality was inferred to be caused by the deficiency in blood or oxygen supply ${ }^{2}$. On the other hand, we showed that the quail embryos could be successfully cultured in two kinds of in vitro systems, i.e., mineral-rich (MR: using chicken egg shell) and mineral-free (MF:using Saran Wrap $\left.{ }^{\circledR}\right)$ culture ${ }^{3,4}$.

It seems interesting to observe the development of the above mentioned homozygous and heterozygous embryos under in vitro culture condition. This attempt has been performed and the present report is concerned with (1) the developmental stages at which the $B h$ homozygous embryos die, (2) effects of $B h$ gene on development of the liver and (3) ultrastructural observation on development of the embryonic liver in in vitro culture.

\section{Materials and Methods}

Embryos. The crossbred between BH (black at hatch) and WP (wild type plumage) strains were used for the present study. Description on these two strains is given elsewhere ${ }^{2,5,6)}$. Embryos were taken from two types of matings, $B h /+\times B h /+$ (experimental mating) and $B h /+x+/+$ (control mating: includes reciprocal matings).

Culture vessels Two kinds of culture methods, i.e., mineral-rich (MR) and mineralfree (MF) culture, were adopted. In MR method, a culture vessel was made of the narrow end half of the chicken egg shell. Whereas, MF culture was performed with hemispherical pouch made of Saran Wrap ${ }^{\circledR}$ (Fig. 1). Embryos and associated contents of the egg were transferred to the culture vessels after 2.5 days of normal incubation. After the culture vessels were covered with petri dish, they were cultured in a $\mathrm{CO}_{2}$ incubator at $37.5^{\circ} \mathrm{C}$ with almost $100 \%$ relative humidity and 1.0 to $1.5 \% \mathrm{CO}_{2}$ in air. More detailed description on culture technique is given elsewhere $\mathrm{e}^{3,4,7)}$.

Observation of embryos Embryos from the experimental and control matings were 
cultured, and their development was checked twice a day. Embryos were considered to be dead when they did not show gross movement, and there was no sign of circulation in the chorioallantoic vascular system ${ }^{8}$. Developmental stages of embryos were determined according to the criteria described by $Z_{\mathrm{ACCHEI}}{ }^{9)}$. Culture experiment was stopped at 12 days of incubation and all living embryos were sacrificed. Wet weight of the embryo and length of the right third toe were measured as the criteria for indicating developmental stage of the embryo ${ }^{10)}$. Subsequently, the genotype of the embryo was determined by the pigmentation pattern of the down feathers, and then gross observation of liver was performed with naked eye or under a dissecting microscope.

Ultrastructural studies. Liver samples from MR and MF culture embryos at 12 days of incubation and those from the normal embryos at 10 days of incubation were transferred for ultrastructural observation. The liver was dissected out, cut into small pieces and fixed

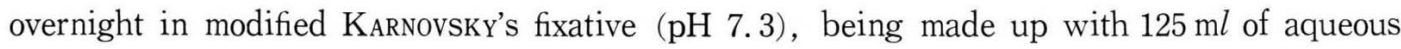
solution containing $2.8 \%$ glutaraldehyde and $3.2 \%$ paraformaldehyde, $100 \mathrm{ml}$ of $0.2 \mathrm{M}$ S $\phi$ RENSEN phosphate buffer and $25 \mathrm{~m} l$ of $\mathrm{s}$-collidin. After fixation, the tissue was washed in $0.1 \mathrm{M}$ S $\phi$ RENSEN phosphate buffer containing $3 \%$ sucrose $(\mathrm{pH} 7.4)$. They were then post-fixed by $2 \%$ osmium tetraoxide in $0.1 \mathrm{M}$ S $\phi$ RENSEN phosphate buffer for 2 hours, dehydrated with ethyl alcohol and embedded in Quetol 812. One $\mu \mathrm{m}$ sections for light microscopy were stained with toluidine blue. Thin sections for electron microscopy were stained with uranyl acetate ${ }^{11)}$ and modified lead staining methods ${ }^{12}$ and examined with a JEOL $100 \mathrm{CX}$ electron microscope at $100 \mathrm{kV}$.

Statistical analysis Statistical analysis of experimental data was performed with AsPINWeLch's Method for $t$-test ${ }^{13)}$. Difference was regarded as significant at the level, $\mathrm{p}\langle 0.05$.

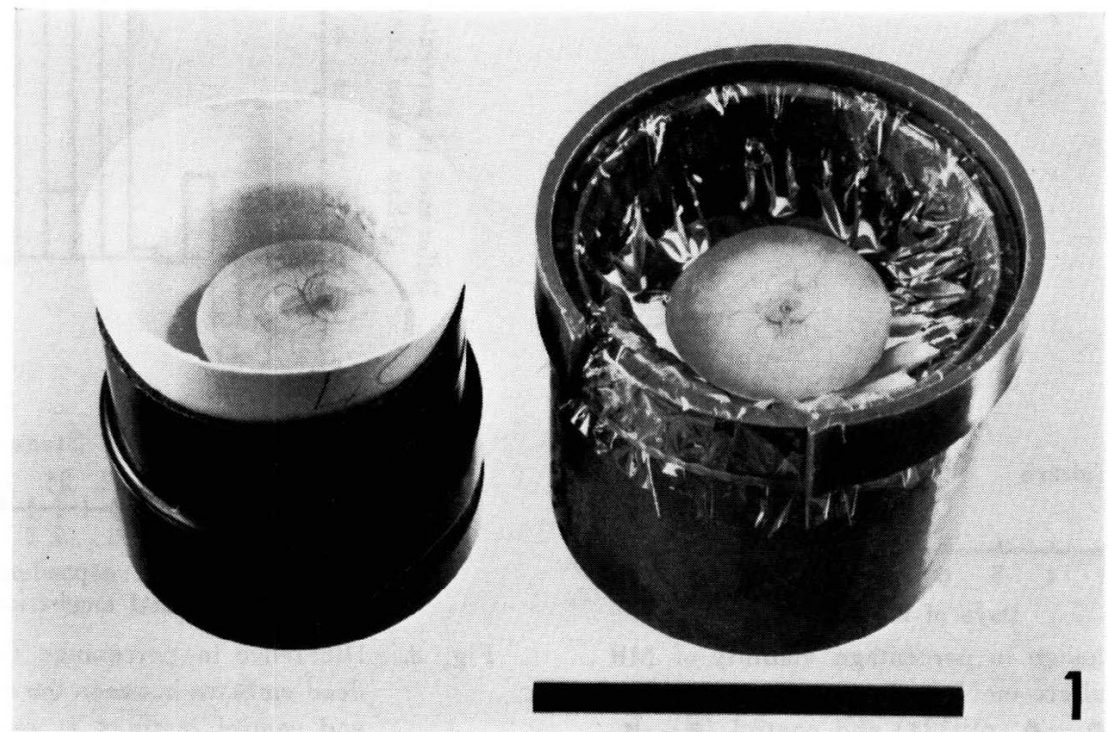

Fig. 1. Fully prepared MR (left) and MF (right) culture vessels containing the quail embryos and associated egg contents at 2.5 days of normal incubation. Chicken egg shell was used in MR culture and Saran Wrap $\mathbb{R}$ in MF culture, Bar indicates $5 \mathrm{~cm}$, 


\section{Results}

Viability of MR culture embryos from the experimental and control matings is shown in Figure 2. They showed excellent viability until 5.5 days of incubation (2.5 days of normal incubation plus 3 days of culture). Thereafter, embryos from the experimental mating showed lower viability than those from the control mating, and the difference amounted to $24 \%$ at 8.5 days. Figure 3 shows differences in incidence of dead embryos between two types of matings at each developmental stage in MR culture. The difference was largest at Stages 22 to 25 (corresponding to 6 to 8 days of normal incubation). Viability of MF culture embryos from two types of matings is shown in Figure 4. They also showed excellent viability until 5 days of incubation. Thereafter, viability of embryos from the experimental mating gradually declined beneath that of the control mating and the difference was $19 \%$ and $23 \%$ at 9 and 10 days of incubation, respectively. Figure 5 shows differences in incidence of dead embryos at each developmental stage. The difference was greatest at Stages 24 to 25 (corresponding to 8 days of normal incubation). These differences in viability and frequency distribution of dead embryos indicated that the $B h$ homozygous embryos died at 5.5 to 8.5 days of incubation (Stages 19 to 25 : corresponding to 4.5 to 8 days of normal incubation) in MR

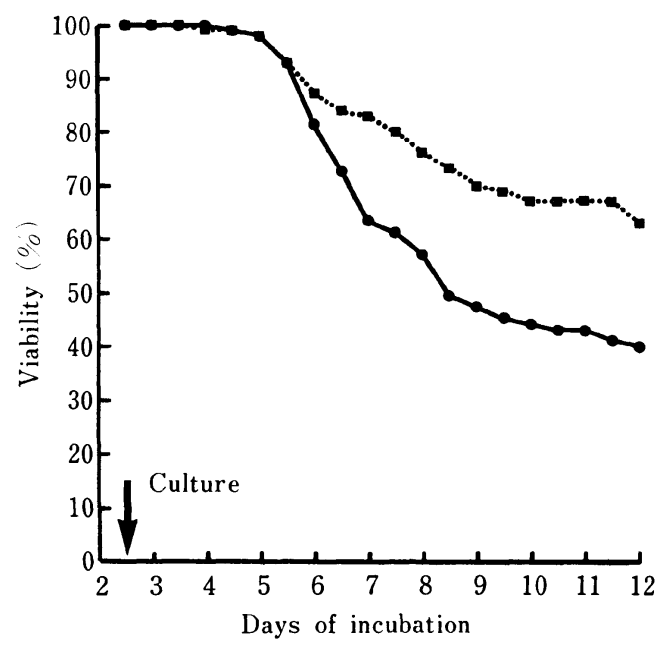

Fig. 2. Change in percentage viability of MR culture embryos from tne experimental $(\bullet, \mathrm{n}=134)$ and control $(\mathbf{\square} \cdots \mathbf{m}$, $\mathrm{n}=86$ ) matings. Culture was commenced at 2.5 days of normal incubation.

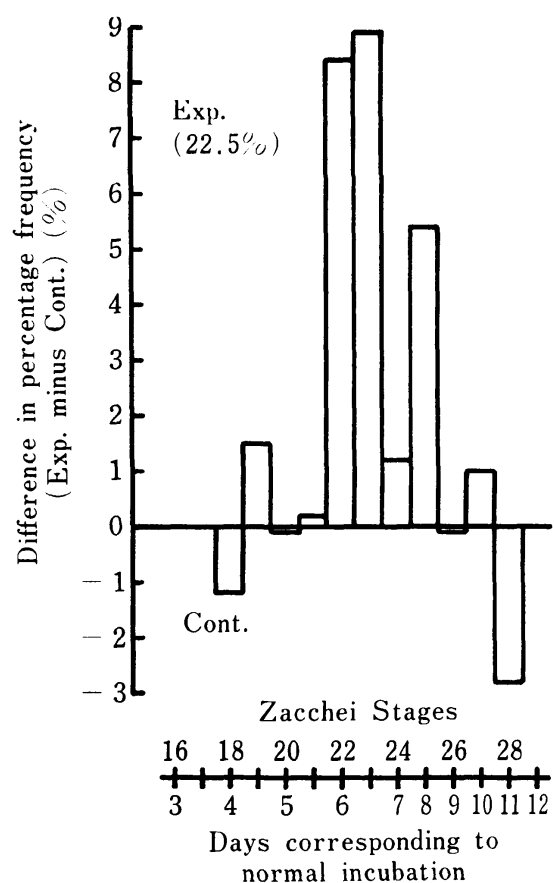

Fig. 3. Difference in percentage frequency of dead embryos between the experimental and control matings at each developmental stage of $Z_{\mathrm{ACCHEI}}{ }^{9)}$ in MR culture. The number in parenthesis indicates the difference in total percentage mortality between two types of matings. 


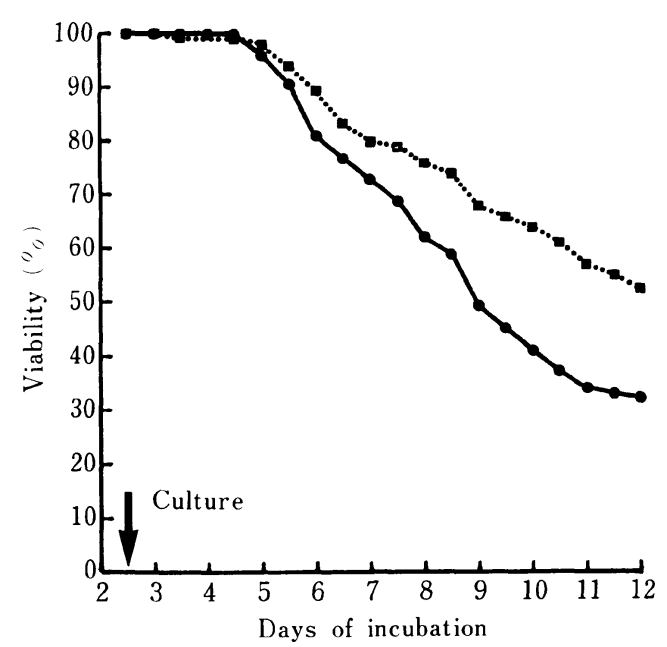

Fig. 4. Change in percentage viability of MF culture embryos from the experimental $(\bullet-\bullet, \mathrm{n}=206)$ and control $(\mathbf{\square} \cdots \mathbf{m}$, $\mathrm{n}=173$ ) matings. Remainder of legend is the same as in Fig. 2.

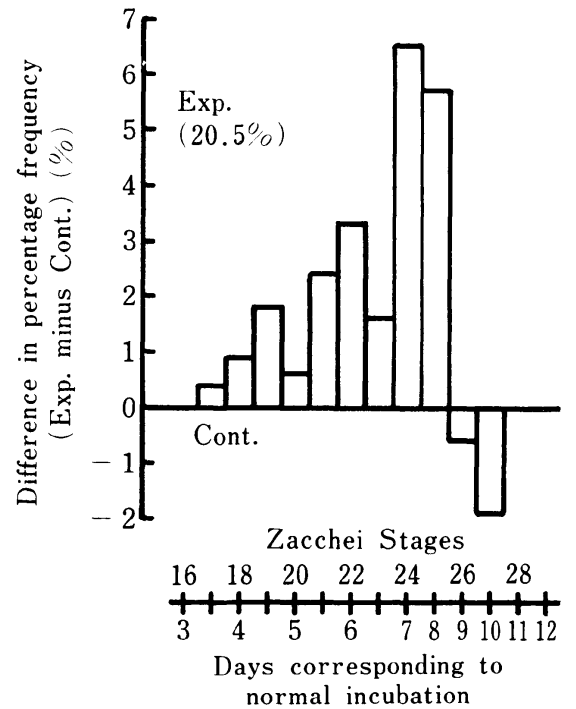

Fig. 5. Difference in percentage frequency of dead embryos between the experimental and control matings at each developmental stage of $\mathrm{ZACCHEI}^{9)}$ in MF culture. Remainder of legend is the same as in Fig. 3.

culture and at 5 to 9 days of incubation (Stages 17 to 25: corresponding to 3.5 to 8 days of normal incubation) in MF culture. This is consistent with the previous finding that lethal stage of the homozygous embryos developed in ovo was 4 to 9 days of incubation ${ }^{2}$. Characteristics of the homozygous embryos in culture was whole body subcutaneous haemorrhage and degeneration of the liver tissue as shown by those developed in ovo ${ }^{1,2}$. In some of the moribund homozygous embryos, air bubbles were found in the capillaries of chorioallantoic membrane, and they seemed to be obstructive to blood stream. Cultured embryos showed delay of development when compared to those developed in ${ }^{2} \mathrm{o}^{4)}$. At 10 days of incubation, it was less than half a day and about one day in MR and MF culture, respectively.

On dissection at 12 days of incubation, it was possible to distinguish between $B h$ and wild type embryos by the pigmentation pattern. The segregation ratio was approximately $2: 1$ and $1: 1$ in the experimental and control matings, respectively. Therefore, all the $B h$ type embryos at this stage were regarded as the heterozygotes for $B h$ gene. Local degeneration of the liver tissue was found at the posterior tip of the lobe in some of those embryos (Figs. 6 and 7). Its incidence in the $B h$ and wild type embryos is shown in Table 1. In MR culture the incidence was about $50 \%$ in both $B h$ and wild type embryos for the left lobe, and about $20 \%$ of the $B h$ type embryos and $4 \%$ of the wild type showed the degeneration in both left and right lobes. In MF culture the incidence was about $80 \%$ in both types of embryos for the left lobe, and about $20 \%$ of the $B h$ type and $10 \%$ of the wild type had the abnormality in both lobes. No embryos showed the abnormality at the right lobe only. 

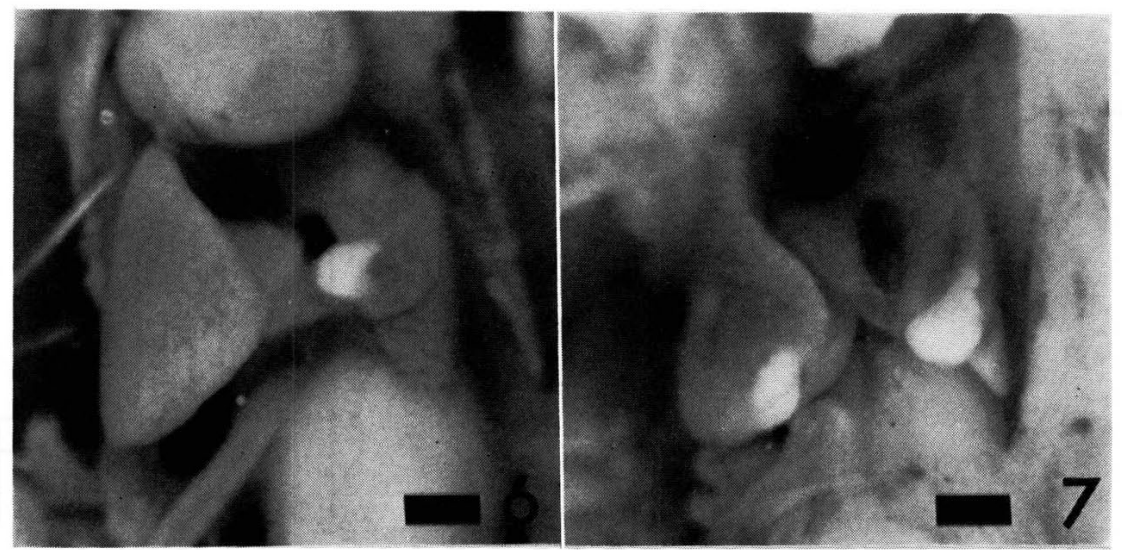

Fig. 6. The MF culture embryo at 12 days of incubation showing degeneration of the liver tissue at the posterior tip of the left lobe. Bar indicates $1 \mathrm{~mm}$.

Fig. 7. The MR culture embryo at 12 days of incubation showing degeneration of the liver at the posterior tip of both lobes. Bar indicates $1 \mathrm{~mm}$.

Table 1. Incidence of local degeneration of the liver

\begin{tabular}{|c|c|c|c|c|}
\hline \multirow[t]{3}{*}{ Genotypes } & \multicolumn{2}{|c|}{$[B h /+]$} & \multicolumn{2}{|c|}{$[+/+]$} \\
\hline & \multicolumn{4}{|c|}{ Degeneration at } \\
\hline & $\mathrm{R}$. & L. & $\mathrm{R}$. & L. \\
\hline MR culture & $\begin{array}{l}10 / 55^{*} \\
(18 \%)\end{array}$ & $\begin{array}{l}31 / 55 \\
(56 \%)\end{array}$ & $\begin{array}{l}2 / 51 \\
(4 \%)\end{array}$ & $\begin{array}{l}23 / 51 \\
(45 \%)\end{array}$ \\
\hline MF culture & $\begin{array}{l}19 / 87 \\
(22 \%)\end{array}$ & $\begin{array}{l}73 / 87 \\
(84 \%)\end{array}$ & $\begin{array}{l}6 / 68 \\
(9 \%)\end{array}$ & $\begin{array}{l}53 / 68 \\
(78 \%)\end{array}$ \\
\hline $\begin{array}{l}\text { Normal } \\
\text { (in ovo) ** }\end{array}$ & $\begin{array}{c}1 / 572 \\
(0.2 \%)\end{array}$ & $\begin{array}{c}205 / 572 \\
(36 \%)\end{array}$ & $\begin{array}{c}1 / 448 \\
(0.2 \%)\end{array}$ & $\begin{array}{c}34 / 448 \\
(8 \%)\end{array}$ \\
\hline
\end{tabular}

Observation was performed at 12 days of incubation for the MR and MF culture embryos and at 10 and 12 days for those developed in ovo. *Incidence of embryos showing the degeneration (percent frequency). **Data from ONo and WAKASUGI ${ }^{2)}$. R., right lobe; L, left lobe.

Table 2 shows body weight and right third toe length of MR and MF embryos at 12 days of incubation. The MR embryos showed better growth than MF embryos as a whole. In MR culture, body weight of the wild type embryo was significantly heavier than the $B h$

Table 2. Body weight and right third toe length of $B h$ and wild type embryos at 12 days of incubation

\begin{tabular}{llccc}
\hline $\begin{array}{l}\text { Types of } \\
\text { incubation }\end{array}$ & genotypes & $\begin{array}{c}\text { No. of embryos } \\
\text { examined }\end{array}$ & $\begin{array}{c}\text { Body weight } \\
(\mathrm{g}) \pm \mathrm{SE} .\end{array}$ & $\begin{array}{c}\text { Right third toe } \\
\text { length }(\mathrm{mm}) \pm \mathrm{SE} .\end{array}$ \\
\hline M R & {$[B h /+]$} & 55 & $1.66 \pm 0.05^{*}$ & $7.11 \pm 0.14$ \\
culture & {$[+/+]$} & 51 & $1.82 \pm 0.05$ & $7.40 \pm 0.12$ \\
M F & {$[B h /+]$} & 87 & $1.34 \pm 0.02$ & $4.76 \pm 0.06^{*}$ \\
culture & {$[+/+]$} & 68 & $1.39 \pm 0.03$ & $4.94 \pm 0.07$ \\
\hline
\end{tabular}

*Significantly different from that of wild type embryos $(\mathrm{P}<0.05)$. 
Table 3. Body weight and right third toe length of 12 days' embryos with or without local degeneration of the liver

\begin{tabular}{llccc}
\hline $\begin{array}{l}\text { Types of } \\
\text { incubation }\end{array}$ & $\begin{array}{l}\text { Site of local } \\
\text { degeneration }\end{array}$ & $\begin{array}{c}\text { No. of embryos } \\
\text { examined }\end{array}$ & $\begin{array}{c}\text { Body weight } \\
(\mathrm{g}) \pm \mathrm{SE} .\end{array}$ & $\begin{array}{c}\text { Right third toe } \\
\text { length }(\mathrm{mm}) \pm \mathrm{SE} .\end{array}$ \\
\hline \multirow{3}{*}{ MR culture } & neither lobe & 55 & $1.87 \pm 0.05^{\mathrm{a}}$ & $7.51 \pm 0.12^{\mathrm{a}}$ \\
& left lobe only & 39 & $1.65 \pm 0.06^{\mathrm{b}}$ & $7.07 \pm 0.15^{\mathrm{b}}$ \\
& both lobes & 12 & $1.45 \pm 0.06^{\mathrm{c}}$ & $6.51 \pm 0.23^{\mathrm{b}}$ \\
MF culture & neither lobe & 29 & $1.41 \pm 0.04^{\mathrm{a}}$ & $4.82 \pm 0.13^{\mathrm{a}}$ \\
& left lobe only & 101 & $1.37 \pm 0.02^{\mathrm{a}}$ & $4.90 \pm 0.05^{\mathrm{a}}$ \\
& both lobes & 25 & $1.27 \pm 0.04^{\mathrm{b}}$ & $4.61 \pm 0.12^{\mathrm{b}}$ \\
\hline
\end{tabular}

The values marked with different letters are significantly different in each culture condition $(\mathrm{P}<0.05)$.

type. Significant difference was also seen in right third toe length between the $B h$ type embryo and the wild type in MF culture. The data on these two parameters were rearranged according to the presence or absence of local degeneration of the liver and the result is shown in Table 3. In MR culture the embryo without the abnormality showed heavier body weight and longer right third toe. Body weight of the embryos with the abnormality in both lobes was lighter than those having the abnormality in the left lobe only. In MF culture the abnormality in both lobes showed smaller body weight and shorter right third toe than the embryos having the abnormality at the left lobe only or those having no abnormality.

Observation of one $\mu \mathrm{m}$ section stained with toludine blue revealed that degenerated cells of the liver was clearly discernible from adjacent healthy cells. Large lipid droplets were found in some of both healthy and degenerated liver cells of cultured embryos and they were more numerous as compared with the embryos developed in ovo. The following features were found with ultrastructural observation of the degenerated cells. Cytoplasm was thin and scattered. Mitochondria with dense matrix and numerous cristae and numerous lysosomes were frequently seen in the cytoplasm, whereas no glycogen granules were found (Fig. 8). Glycogen granules were usually present in the healthy hepatic cells (Fig. 9). Ultrastructural feature of the degenerated cells was similar regardless of the genotypes of embryos or whether the samples were taken from cultured embryos or from those developed in ovo.

\section{Discussion}

Recent research on shell-less culture of the chicken ${ }^{7,8,14,15,16,17)}$ and quail ${ }^{3,4)}$ embryos has suggested that lack of external calcium supply may be one of the severe limitations for embryonic development during the secoud half of incubation. We have demonstrated that about $80 \%$ of calcium and 25 to $30 \%$ of magnesium possessed by the newly hatched chicks are derived from the egg shell in normal incubation, and that MR culture is more suitable than the MF culture for embryonic development ${ }^{4}$. In the present study also, the embryos in MR culture showed better development than those in MF culture in several aspects such as body weight and right third toe length at 12 days of incubation. Embryos from the control mating in both MR and MF culture showed lower viability than in the 

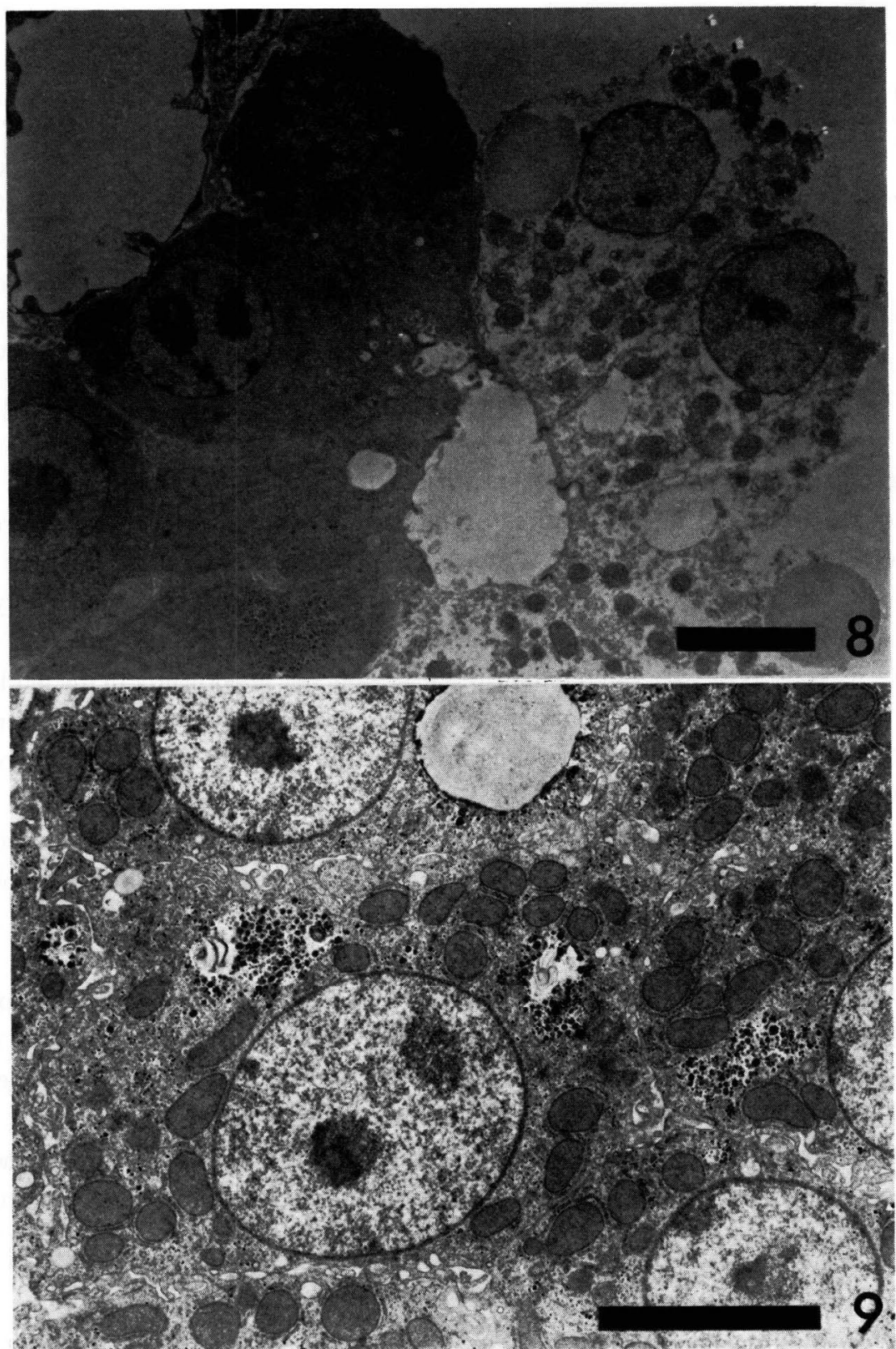

Fig. 8. Ultrastructure of the locally degenerated area at the posterior tip of the right liver lobe. This sample was taken from the wild type MF culture embryo at 12 days of incubation. Note the clear separation between degenerated (right) and healthy (left) regions. Large lipid droplets, mitochondria with dense matrix and numerous cristae and no glycogen granules are seen in the degenerated cells. Bar indicates $5 \mu \mathrm{m}$.

Fig. 9. Ultrastructure of the normal liver cells with glycogen granules. This sample was taken from the wild type MF culture embryo at 12 days of incubation. Note presence of both aggregated and scattered glycogen granules. Bar indicates $5 \mu \mathrm{m}$. 
previous studies, ${ }^{3,4}$. This difference is not attributed to weakness of $B h$ heterozygous embryos, because segregation ratio of the $B h$ and wild type embryos at 12 days of incubation was normal, i.e., the viability of two types of embryos was almost the same. Embryos used in the previous studies were $F_{1}$ hybrids produced by crosses of the wild type quail from two different stocks, whereas, in the present study $F_{2}$ embryos were used. It is often observed in breeding experiments of Japanese quail that $F_{1}$ embryos show better viability than the $F_{2}$. The difference mentioned above might be an expression of such phenomenon.

The lethal stage attributed to the $B h$ gene was not altered by an artificial environment. Some of the moribund homozygous embryos contained air babbles in the capillaries of chorioallantoic membrane, and they seemed to be obstructive to blood stream. This phenomenon is thought to be related to the whole body subcutaneous haemorrhage, i.e., it suggests that weakening of capillaries occur not only in the embryo body but also in the extraembryonic tissues.

Local degeneration of the liver tissue at the posterior tip of the lobe is thought to be caused by dysfunction of the capillaries or the deficiency in blood or oxygen supply ${ }^{2}$. This possibility may be suggested also by two interrelated findings as follows; (1) the incidence of this abnormality was higher in the $B h$ heterozygotes than in the wild type, and (2) the $B h$ homozygous lethal embryos showed whole body subcutaneous haemorrhage (abnormality of capillaries). On the other hand, the incidence of this abnormality was higher in cultured embryos than in those developed in ovo. Therefore, it is further inferred that the deficiency in blood or oxygen supply might easily occur at the posterior tip of the left lobe of the liver in culture condition, especially in MF culture in which there is little external supply of minerals, such as calcium and magnesium ${ }^{4}$. There is also other possibility that the abnormality might be enhanced by some factors from artificial culture environment, such as lack of turning ${ }^{8)}$, abnormal chamber geometry ${ }^{15)}$, restricted albumen uptake ${ }^{8)}$ and restricted development of the chorioallantoic membrane ${ }^{3)}$, since these factors are thought to lead to reduced respiration of the embryos.

Development of the $B h$ heterozygous embryos seemed to be inferior to that of wild type in both MR and MF culture (Table 2). Frequency of embryos showing local degeneration of the liver tissue in both lobes was higher in $B h$ type embryos, and body weight and right third toe length of these embryos were inferior as compared with the embryos having the abnormality in the left lobe only or no abnormality (Tables 1 and 3). Thus, the difference in these two parameters between the $B h$ and wild type embryos may reflect the extent of the degen-eration of liver tissue.

Histological observation of the liver from the cultured embryos indicated that there were many large lipid droplets in the healthy cells as well as in the degenerated cells. The increase in number of large lipid droplets has been observed in the liver cells of chick embryos maintained in shell-less culture ${ }^{18}$. Chick embryos treated with sulfamides showed a great increase in the number of lipid droplets in the liver cells. However, it occurred without a corresponding increase in total content of lipid in the liver ${ }^{19}$. Therefore, the increase in number of lipid droplets in liver cells of cultured embryos is thought to indicate 
some disturbance in lipid metabolism as suggested by Narbaitz et al. ${ }^{18)}$. However, it is unknown whether there is any relationship between abnormal increase in number of large lipid droplets and deficiency in blood or oxygen supply.

NARBAITz et al. ${ }^{18)}$ reported that few or no glycogen granules were found in the liver cells of chick embryos that were cultured with plastic petri dish method ${ }^{7,20}$. Whereas, in the present study, glycogen granules were usually found in the healthy hepatic cells in both MR and MF embryos. NARBaItz et al. ${ }^{18)}$ stated that the decrease of glycogen granules from cultured embryos did represent neither a decrease in the synthesis nor an increase in consumption of glycogen. They suggested that glycogen might be present in a different physiochemical state so that it was dissolved by the fixation and embedding process. The discrepancy between the two experiment may be attributed to the slight difference in the histological procedure.

\section{Summary}

Homozygous and heterozygous embryos for $B h$ gene were cultured with mineral-rich (MR: using chicken egg shell) and mineral-free (MF: using Saran Wrap ${ }^{\circledR}$ ) methods after 2.5 days of normal incubation. The homozygotes died at Stages 19 to 25 of ZACCHEI's standardization (corresponding to 4.5 to 8 days of normal incubation) in MR culture and at Stages 17 to 25 (corresponding to 3.5 to 8 days of normal incubation) in MF culture. These lethal stages were almost the same as that of the homozygous embryos developed in ovo and characteristic syndromes of the lethal embryos were likewise degeneration of the liver tissue and whole body subcutaneous haemorrhage. The findings that some of the moribund homozygous embryos contained air babbles in the capillaries of the chorioallantoic membrane suggested that weakening of capillaries occurred not only in the embryo body but also in the extraembryonic tissues. Local degeneration of liver tissue was found at the posterior tip of the liver in some embryos at 12 days of incubation. Incidence of this abnormality in the left lobe was higher in MF embryos (about $80 \%$ ) than in MR embryos (about $50 \%$ ) regardless of the genotypes. The incidence in the right lobe was higher in the $B h$ type embryos (about $20 \%$ ) than in the wild type (about $7 \%$ ). With regard to the embryos developed in ovo, the incidence in the left lobe was $36 \%$ and $8 \%$ in the $B h$ and wild type, respectively, and that in the right lobe was $0.2 \%$ in both genotypes. Thus, incidence of this abnormality was enhanced under the culture condition and in the $B h$ type embryos. Ultrastructural observation revealed increase in number of large lipid droplets in liver cells of cultured embryos. In the region showing local degeneration of liver tissue, the degenerated cells were clearly discernible from the adjacent healthy cells. Characteristics of the degenerated cells were as follows. Cytoplasm was thin and scattered. Mitochondria with dense matrix and numerous cristae and numerous lysosomes were frequently seen, whereas no glycogen granules were found. Ultrastructural feature of the degenerated cells was similar regardless of the genotypes of embryos or whether the samples were taken from the cultured embryos or those developed in ovo. 


\section{Acknowledgements}

The authors wish to thank Mrs. T. Hayakawa for taking care of animals. This study was supported by Grant No. 82-16-08 form National Center for Nervaous, Mental and Muscular Disorders (NCNMMD) of the Ministry of Health and Welfare, Japan.

\section{References}

1) Minezawa, M. and N. Wakasugi (1977). Studies on a plumage mutant (black at hatch) in the Japanese quail: Jpn. J. Genetics, 52: 183-195.

2) Ono, T. and N. Wakasugi (1983). Abnormalities in liver morphogenesis attributed to the $B h$ (black at hatch) lethal gene in the Japanese quail: Japan. Poult. Sci., 20: 158-169.

3) Ono, T. and N. Wakasugi (1983). Development of cultured quail embryos: Poultry Sci., 62: $532-536$.

4) Ono, T. and N. Wakasugi (1983). Mineral content of quail embryos cultured in mineral-rich and mineral-free conditions: Poultry Sci., in press.

5) Kaтон, H. and N. Wakasugi (1981), Studies on blood groups in the Japanese quail: The common antigens possessed by red blood cells and leukocytes, and their interitance: Immunogenetics, 13: $109-114$.

6) Somes, R. G. JR. (1981). International Registry of Poultry Genetic Stocks, pp 16-17: Storrs Agricultural Experimentation Station Publications, University of Connecticut, Storrs.

7) Auerbach, R., L. Kubai, D. Knighton and J. Folkman (1974). A simple procedure for long-term cultivation of chicken embryos: Dev. Biol., 41: 391-394.

8) Dunn, B.E. and M. A. Boone (1976). Growth of the chick embryo in vitro: Poultry Sci., 55: 1067-1071.

9) Zacchei, A. M. (1961). Lo sviluppo embrionale dela quagilia giapponese (Coturnix coturnix japonica T. e S. ): Arch. Ital. Anat. Embriol., 66: 36-62.

10) Hamburger, V. and H. L. Hamilton (1951). A series of normal stages in the development of the chick embryo: J. Morphol., 88: 49-92.

11) Watson, M. L. (1958). Staining of tissue sections for electron microscopy with heavy metals: J. Biophys. Biochem. Cytol. 4. 475-478.

12) Sato, T. (1968). A modified method for lead staining of thin sections: J. Electron Microsc., 17: 158-159.

13) Snedecor, G. W. and W. G. Cochran (1980). Statistical Methods. 7 th ed.: Iowa State Univ. Press, Ames, IA.

14) Dunn, B. E. and M. A. Boone (1977). Growth and mineral content of cultured chick embryos: Poultry Sci., 56: 662-672.

15) Dunn. B.E. and M. A. Boone (1978). Photographic studies of chick embryo development in vitro. Poultry Sci., 57: 370-377.

16) De Gennaro, L. D., D. S. Packard, Jr., R. W. Stach and B. J. Wagner (1980). Growth and differentiation of chicken embryos in simplified shell-less cultures under ordinary conditions of incubation: Growth, 44: 343-354.

17) Watanabe, K. and K. Imura (1983). Significance of the egg shell in the development of the chick embryo: A study using shell-less culture: Zool. Mag., 92: 64-72.

18) Narbaitz, R., S. Kacew and B. Burke (1980), Ultrastructural and biochemical alterlations in the livers from chick embryos maintained in shell-less culture: Anat. Embryol., 159: 307-316.

19) Romanoff, A. L. (1960). The Avian Embryo. Structural and functional development: New York, MacMillan.

20) Dunn, B. E., T. P. Fitzharris and B. D. Barnetr (1981). Effects of varying chamber construction and embryo pre-incubation age on survival and growth of chick embryos in shell-less culture: Anat. Rec., 199: 33-43. 


\title{
培養条件下におけるニホンウズラの black at hatch $(B h)$ 致死胚の観察と肝形成異常
}

\author{
小野珠乙・若杉昇 \\ 名古屋大学農学部 名古屋市 $\bar{\top} 464$
}

ミネラル・リッチ (MR：ニワトリ卵殼による培養) およびミネラル・フリー（MF：サランラップ®による培 養) 法によって $B h$ ホモ型ならびにへテロ型胚を正常卵 卵 2.5 日より培養した。ホモ型胚の死亡時期は，MR 培 養においては Z ACCHEI の発生ステージ19２5 (正常卵期 4. 5〜8 日に相当), $M F$ 培養においてはステージ $17 \sim 25$ (正常卵孚卵3.5〜8 日に相当) であった。また培養条件下 におけるホモ型肧の死亡時期は正常孵卵の場合とほぼ同 一であり，その特徵も同様に肝葴組織の变性と全身皮下 出血であった。瀕死の木モ型胚に扣いて漿尿膜のも細血 管内に気泡を含む胚が観察された。このことより毛細血 管減弱は胚体内だけではなく胚体外組織にも生じること が示唆された。卵卵12日（正常卵脬卵2.5日および培荃9.5 日）に扣いて, 肝蔵後端部に局所的変性を示す肧が観察 された。この異常の出現率は肝蔵左葉に抏いては MF 培 養胚の方が MR 培養胚より高く（それぞれ約 $80 \%$ おび $50 \%)$, 遺伝子型 (Bhへテロ型および野生型)による差
は認められなかった。肝臓右葉の異常に関しては, $B h$ ヘテロ型胚の方が野生型胚より高かった（それぞれ約 20

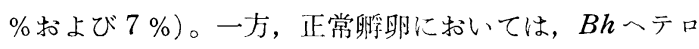
型胚の $36 \%$ および野生型胚の $8 \%$ に肝臓左葉の異常が認 められ, 右葉に異常を示す胚は両遺伝子型とも $0.2 \%$ で あった。したがってこの異常の出現率は培養条件下およ び $B h$ 八テロ型肧において增加することが明らかにされ た。電影観察により, 培養胚の朋蔵細胞では下大脂肪滴 の増加が認められた。局所的变性の認められた肝臓組織 では正常細胞の領域と変性細胞の領域とが隣接して存在 した。変性細胞の特徵はまばらな細胞質, 高密度の基質 および多数のクリステをもつミトュンドリアならびに多 数のライソゾームを有し, グリコーダン顆粒を有しない ことであった。これらの特徵は肧の遺伝子型および培養 (卵稂) 万法の違いにかかわらず同様であった。

(家㷆会誌，20，370～380，1983） 